\title{
Daily Dietary Nutrition and Nutraceutical Intake in Agricultural Laborers of Hirakud Command Area, Sambalpur, Odisha, India
}

\author{
Monalisa Pradhan1*, Pravabati Guru², Biswaranjan Paital ${ }^{3}$ \\ ${ }^{1}$ Krishi Vigyan Kendra, Sambalpur, Chiplima, Odisha \\ ${ }^{1}$ Department of Home Science, Sambalpur University Jyoti Vihar-768019, Sambalpur, Odisha \\ 2 Regional Directorate of Education, Sambalpur, Odisha \\ ${ }^{3}$ Redox Regulation Laboratory, Department of Zoology, Odisha University of Agriculture and Technology, College of Basic Science and \\ Humanities, Bhubaneswar-751003, Odisha, India
}

\begin{abstract}
Sambalpur is considered as the rice bowl of Odisha for its cultivation activities due to the presence of hydroelectric power house Hirakud Dam, with total capacity of $5,896,000,000 \mathrm{~m}^{3}, 55 \mathrm{~km}$ long and is one of the first major multipurpose river valley projects started after India's independence. It irrigates about $75,000 \mathrm{~km}^{2}\left(19 \times 10^{6}\right.$ acres $)$ of land and therefore, is considered as a blessing to the farmer families. As because of cultivation and allied activities, Agricultural Laborers (ALs) constitute a large portion of the active work force. Study on the nutritional intake in this important fraction of population is lacking. Present study was an attempt to know the food consumption pattern and nu tritional intakes of ALs in Hirakud command area of Sambalpur district, India. Data were collected from 300 ALs, consisting of 150 from each gender. Daily dietary pattern and nutritional intake of respondent were calculated through 24 hours dietary recall method. It was observed that ALs consume all most all the food varieties available in Odisha. Cereal consumption was 6.80 and $1.77 \%$ excess than the recommend value dietary allowance (RDA) by Indian Council for Medical Research (ICMR, in 1990). Except cereals, all other food consumption was below the RDA value in ALs. The intake of other food varieties in ALs was $>60 \%$ deficit from the RDA values. Consumption of milk was $97 \%$ less in case of male ALs and $98 \%$ less in case of female ALs in comparison to the values suggested in RDA. Similarly, consumption of all nutrients was less than RDA norms except Vitamin -C in case of male ALs. The consumption of Niacin and Vitamin - $\mathrm{C}$ was excess in case of female ALs. Alternate low cost food supply is suggested to compensate such insufficient nutritional uptake by ALs in the study area.
\end{abstract}

Keywords: Food, nutrient intake, nutraceuticals, nutritional status, 24 hours recall method

Article Info: Received 19 June 2019; Review Completed 19 Aug 2019; $\quad$ Accepted 28 Aug 2019; Available online 15 Sep 2019

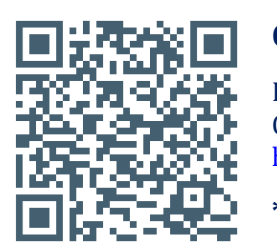

\section{Cite this article as:}

Pradhan M, Guru P, Paital B,_Daily Dietary Nutrition and Nutraceutical Intake in Agricultural Laborers of Hirakud Command Area, Sambalpur, Odisha, India , Journal of Drug Delivery and Therapeutics. 2019; 9(5):56-61 http://dx.doi.org/10.22270/jddt.v9i5.3443

Biswaranjan Paital, Redox Regulation Laboratory, Department of Zoology, Odisha University of Agriculture and Technology, College of Basic Science and Humanities, Bhubaneswar-751003, Odisha, India

\section{INTRODUCTION}

Nutritional science deals with the interaction of nutrients and other substances in food in relation to maintenance, growth, reproduction, health and disease of an organism. In one hand, it describe the food intake, absorption, assimilation, biosynthesis, catabolism and excretion ${ }^{1-2}$ and on the other hand, it also deals with the nutrition deficiency associated abnormalities and disease $\mathrm{s}^{3}$. It is estimated that 190.7 million (14.5\%) people were undernourished in India during 2014-20164 and the situation even worse in the state Odisha but with an observed improving trend. Although, a constant economic growth is achieved in our country over the last decade, one sixth and one fifth of Indian adult and children are found to be undernourished ${ }^{5}$. So, the ratio between demand and need for nutritional and nutraceuticals in Indian population need to be lower down.

Health problems are rampant in rural area not merely because of lack of medical facilities but because of general poverty, lack of balanced and nutritious diet to large proportion of rural population and more over lack of knowledge with regard to dietary requirements, the nutritive value of different foods and health. Surveys carried out by National Nutrition and Monitoring Bureau over the past decades in rural and urban areas of 10 states of the country have revealed that, the diets of the middle-income groups in urban areas is fairly satisfactory, where-as the diets of the rural people and slum dwellers is inadequate in many aspects which is a cause for the widespread occurrence of malnutrition and deficiency diseases ${ }^{6}$. 
According to population census of India 2001, there are about 402.5 million rural workers of which 127.6 million are cultivators and 107.5 million are agricultural laborers ${ }^{7}$. In other words, pure agricultural workers constitute nearly $58.4 \%$ of the total rural workers, of which $31.7 \%$ are owner cultivators and $26.7 \%$ are mainly agricultural wage earners ${ }^{8}$. The latest available agricultural census data (Govt. of India, Agricultural Census Division, Ministry of Agriculture 2002) also reveal that about $78 \%$ of operational land holding in the country can be classified as marginal and small, having less than 2 hectares. About $13 \%$ holdings have 2 to 4 hectares of land and only $7.1 \%$ have 4 to 10 hectares of land9. The agricultural Census data clearly shows that Indian agriculture is dominated by small and marginal farmers, who are basically subsistence farmers. They provide mainly for self-consumption. However, some of these farmers have to sell their produce immediately after harvest at low prices and buy the same products later at high prices.

Agricultural workers constitute the most neglected class in Indian rural structure. Often they are not in a position to earn just enough to meet their minimum basic needs.They are also frequently exposed to the hazards of unemployment and irregular employment. These work forces do not have any type of private nor social security. Being unorganized, they also do not have the voice to seek better living and working condition. Since, they are unskilled; they have no alternative employment opportunities either ${ }^{10}$. So they do not get adequate nutrition for maintaining good health and normal physical efficiency. In order to achieve the maximum output of work good nutrition is one of the basic requirements. It may be mentioned here that the quality and quantity of nutrients vary not only with age but also with intensity of work.

The food requirement of the people varies greatly depending on various factors. Apart from non-occupational activities like walking, dressing, eating etc the nutrient requirement changes depending upon the various activities that one has to perform in his or her daily occupation such as agricultural activities, stone cutting, loading etc. For example a stone cutter requires and expends more energy than a worker in a factory doing light work. Agricultural workers need a wide range of nutrients to keep them healthy and fit. These nutrients can be derivedfrom the daily diet. For maintaining good health and physical efficiency, the diet should provide adequate amounts of all nutrients. The daily requirements of different nutrients for workers engaged in different types of physical activity have been suggested by different Nutrition committees. There is categorization of worker like light or sedentary worker, moderate worker and heavy worker. Agricultural workers come under the category of heavy worker. Thus, the agricultural worker should follow the RDA table of hard worker of ICMR, India. Farmers also called agriculturists are persons engaged in agriculture, raising crops for food or raw materials. Thus more attention needs to be given to obtain data on the physical and Nutritional status of different categories of Agriculturalworker in different income group, their knowledge and practices regarding health and nutrition.

The hydroelectric power house Hirakud Dam of Sambalpur with a total capacity of $5,896,000,000 \mathrm{~m}^{3}, 55 \mathrm{~km}(34 \mathrm{mi})$ long, irrigates about $75,000 \mathrm{~km}^{2}\left(19 \times 10^{6}\right.$ acres $)$ of land. Its storage capacity of $5.818 \mathrm{~km}^{3}(1.396 \mathrm{cu} \mathrm{mi})$ with grosses of $8.136 \mathrm{~km}^{3}$ (1.952 cu mi) and drains an area of 133,090 $\mathrm{km}^{2}\left(32.89 \times 10^{6}\right.$ acres$)$, more than twice the area of Sri Lanka. The dam provides $1,556 \mathrm{~km}^{2}(384,000$ acres $)$ of Kharif and 1,084 km² (268,000 acres) of Rabi irrigation in districts of Sambalpur, Bargarh, Bolangir, and Subarnpur11-
19. Therefore, it provides a work force to several millions farm folk mainly in Sambalpur, for which it is called as the rice bowl of Odisha state ${ }^{15-19}$. However, the daily average nutritional uptake about the farm folk of Sambalpur is lacking. Therefore, the present study was conducted to know the daily food nutrition intake of the agricultural labourer (AL) in Sambalpur area.

\section{MATERIALS AND METHODS}

The data for this study were obtained from a random sampling method of three hundred agricultural laborers from Hirakud Command Area of Sambalpur district of Odisha. Random sampling was done by coin toss method after assigning number to participants. Out of 300 subjects, 150 numbers were male agricultural laborers and 150 were female agricultural laborers.

Data were collected by administering the pre-tested interview schedule. All the respondents were interviewed personally by the investigator at the place of work, which enabled him/her to get first-hand information. In the present study daily food intake and nutrient intake of the respondents have been calculated. For recording the data, "24 hours recall method" has been used. During the interview the respondents were asked about the food items she/he consumes daily. Accordingly, the food items she / he consumed during the day were recorded. For measuring quantity of the food stuffs i.e. rice, roti, curry, dhal, etc. the katori or the serving spoon etc. were used as measuring units. These were then quantified using the measurements taken by the respondent to prepare such food items. For example, for one katori of rice, the quantity was arrived at considering the standard measurement. The nutrient content of each food item was estimated following the method used in the article by Gopalan et al. ${ }^{20}$. The average quantity of consumption of each of these major food groups and nutrient groups for a laborer for a day were estimated and compared with the quantity recommended as dietary allowances (RDA) for Indians by ICMR 21 . The dietary and nutrient intake has been expressed as percentages in excess or deficit of the recommended dietary allowances 21 .

\section{Statistical analyses}

All sets of data $(n=150)$ in male and female groups were subjected to check for homogeneity of variance and normal distribution. Chi-square test was performed to compare the mean values obtained for male and female. Data were considered as significance at $\mathrm{p}<0.05$ level or at $5 \%$ confidence level.

\section{RESULTS AND DISCUSSION}

\section{Dietary intake pattern}

Table 1 shows the mean per capita daily consumption of different food items of the agricultural laborer of Hirakud Command Area of Sambalpur against the daily recommended and its deviance in percent to RDA. These intakes were compared with the quantity of dietary allowances recommended (NIN).

Cereals: The average intake of cereals was estimated to be $640.84 \mathrm{gm}$ by the male agricultural laborer and $488.52 \mathrm{gm}$ by the female agricultural laborer. It was found that the cereal intake was in excess by $6.807 \%$ in case of male agricultural laborer and in excess by $1.77 \%$ in case of female agricultural laborer (Table 1). In both the categories (i.e. male and female agricultural laborer) the cereal intake was found to be excess.

Pulses: The daily mean intakes of pulses by the male and female agricultural laborer were $23.19 \mathrm{gm}$ and $16.55 \mathrm{gm}$ 
respectively. This quantity of consumption was found to be very less in comparison to the RDA. It was $80.67 \%$ deficit in case of male agricultural laborer and $81.6 \%$ deficit in case of female agricultural laborer. Pulses are rich in protein and also supply energy equivalent to carbohydrates. The deficit intake of protein may cause protein energy malnutrition among the respondents.

Green Leafy vegetables and other vegetables: The average consumptions of leafy vegetables by male and female agricultural laborer were found to be $39.51 \mathrm{gm}$ and 39.86 gm respectively which amounted to $60.49 \%$ and $60.14 \%$ deficit of the requirement. Similarly, the intakes of the other vegetables by male and female agricultural laborer were also found to be deficit by $62.64 \%$ and $70.20 \%$ respectively. Leafy vegetables and other vegetables are always considered as protective and regulatory foods. As the intake of these items has been found to be in deficit, the laborers may suffer from vitamin and minerals deficiency related diseases.

Roots and Tubers: The mean intake of roots and tubers by the male agricultural laborer was $111.74 \mathrm{gm}$ and by the female agricultural laborer was 81.14 gm. It was deficit by $44.13 \%$ in case of male agricultural laborer and $59.430 \%$ in case of female agricultural laborer. Roots and tubers helps in increasing the calorie content of the foods and excess or deficit intake may affect the calorie percentage. It has been observed and mentioned above that the cereal intake of the workers was more than the RDA, which may be compensating to some extent, the deficiency arising out of less intake of roots and tubers.

Fruits: The mean intakes of fruits were found to be 11.81 gm and 16.45 gm by male agricultural laborer and female agricultural laborer respectively which was $88.19 \%$ and $89.55 \%$ deficit from the recommended amount.

Table 1. Average daily food intake by agricultural laborer Compared with RDA values.

\begin{tabular}{lcccccc}
\hline & Male & RDA & Excess (+) /Deficit (-) (\%) & Female & RDA & Excess (+) /Deficit (-) (\%) \\
\hline Cereals(gm) & $640.84^{\mathrm{a}}$ & 600 & $(+) 6.807$ & $488.52^{\mathrm{b}}$ & 480 & $(+) 1.775$ \\
\hline Pulses(gm) & $23.19^{\mathrm{a}}$ & 120 & $(-) 80.672$ & $16.55^{\mathrm{b}}$ & 90 & $(-) 81.607$ \\
\hline $\begin{array}{l}\text { Green Leafy } \\
\text { Vegetables(gm) }\end{array}$ & 39.51 & 100 & $(-) 60.493$ & 39.86 & 100 & $(-) 60.140$ \\
\hline Other Vegetables(gm) & $74.71^{\mathrm{a}}$ & 200 & $(-) 62.643$ & $59.59^{\mathrm{b}}$ & 200 & $(-) 70.203$ \\
\hline Roots \& Tubers(gm) & $111.74^{\mathrm{a}}$ & 200 & $(-) 44.130$ & $81.14^{\mathrm{b}}$ & 200 & $(-) 59.430$ \\
\hline Fruits(gm) & 11.81 & 100 & $(-) 88.193$ & 10.45 & 100 & $(-) 89.553$ \\
\hline Meat, Fish \& Egg(gm) & $13.99^{\mathrm{a}}$ & 30 & $(-) 53.356$ & $11.17^{\mathrm{b}}$ & 30 & $(-) 62.778$ \\
\hline Oil \& Fats(gm) & $13.00^{\mathrm{a}}$ & 40 & $(-) 67.500$ & $10.53^{\mathrm{b}}$ & 30 & $(-) 64.911$ \\
\hline $\begin{array}{l}\text { Milk \&Milk } \\
\text { Products(gm) }\end{array}$ & $8.76^{\mathrm{a}}$ & 300 & $(-) 97.080$ & $5.36^{\mathrm{b}}$ & 300 & $(-) 98.213$ \\
\hline Sugar \& Jaggery(gm) & $12.84^{\mathrm{a}}$ & 55 & $(-) 76.655$ & $10.09^{\mathrm{b}}$ & 45 & $(-) 77.570$ \\
\hline
\end{tabular}

Different super scripts $\left({ }^{\mathrm{a}}\right.$ or ${ }^{\mathrm{b}}$ ) used for the mean values in male than their respective female groups are statistically significant at $\mathrm{p}<0.05$ level.

Meat, Fish and Egg: In the survey it is seen that the average daily intakes of non-vegetarian food is 13.99 gm and 11.17 gm by male and female agricultural laborers respectively. This gives a deficit of $53.35 \%$ and $62.77 \%$ as compared to the recommended requirement for male and female laborers respectively. Compared to other food items the deficit in the intake of non-vegetarian food is negligible.

Oils and Fats: The average daily intake of oils and fats has been found to be $13 \mathrm{gm}$ and $10.53 \mathrm{gm}$ by male and female agricultural laborer respectively which is $67.5 \%$ and $64.91 \%$ short of that recommended by RDA. Fats and oils provide extra calories which may compensate the lack of calorie intake from other sources.

Milk and milk products: The average daily intakes of milk and milk products was $8.76 \mathrm{gm}$ and $5.36 \mathrm{gm}$ in case of male and female agricultural laborers respectively which was $97.08 \%$ and $98.23 \%$ deficit compared to RDA. It has been found that maximum consumption of milk is by the respondents who had cow as animal resource. The deficit in both milk and pulses intakes, which are the main source of protein, adversely affect the quality of diet in a substantial way.

Sugar and Jaggery: The average intakes of $12.84 \mathrm{gm}$ and $10.09 \mathrm{gm}$ of sugar were recorded for the male and female agricultural laborer which is $76.65 \%$ and $77.5 \%$ deficit. Most of this sugar consumption came from consumption of tea.

\section{Nutrient Intake}

Table 2 shows the average per capita daily nutrient intake of male and female agricultural laborers with excess and deficit percentage as compared to RDA.

Energy: The daily calorie intakes have been calculated as $2633.43 \mathrm{kcal}$ and $2594 \mathrm{kcal}$ by male and female agricultural laborers respectively. Thus, a deficit by $24.54 \%$ and $8.97 \%$ is noticed from the RDA norm for the male and female laborers, respectively. This is because of the fact that all food groups were taken in less amount (except cereals) and also due to the use of inadequate amount of fats and oils in their diets which affected the calorie intake as recorded in previous table. The result supports the result of Bellurkar (2015) 22 who noticed in her study that the respondents took less calorie.

Protein: The daily requirement of protein as per RDA is 60 gm and 55 gm for the male and female agricultural laborer respectively. But the daily consumption of protein by male and female agricultural laborer has been recorded $20.20 \mathrm{gm}$ and 20.85 gm which is deficit by $66.33 \%$ and $62.09 \%$. This is because milk and pulses intakes were very less as compared to RDA norms. 
Table 2. Average daily nutrient intake by agricultural laborer compared with RDA values.

\begin{tabular}{lllllll}
\hline NUTRIENT & Male & RDA & $\begin{array}{l}\text { Excess (+) } \\
\text { /Deficit (-) (\%) }\end{array}$ & Female & RDA & $\begin{array}{l}\text { Excess (+) } \\
\text { /Deficit (-) (\%) }\end{array}$ \\
\hline CALORIES (Kcal) & $2633.4^{\mathrm{a}}$ & 3490 & $(-) 24.543$ & $2594.25^{\mathrm{a}}$ & 2850 & $(-) 8.974$ \\
\hline PROTEIN (gm) & 20.20 & 60 & $(-) 66.333$ & 20.85 & 55 & $(-) 62.097$ \\
\hline IRON (mg) & 10.78 & 17 & $(-) 36.573$ & 10.57 & 21 & $(-) 49.687$ \\
\hline CALCIUM (mg) & 346.95 & 600 & $(-) 42.174$ & 346.33 & 600 & $(-) 42.278$ \\
\hline VITAMIN A ( $\mathbf{g g})$ & $346.56^{\mathrm{a}}$ & 600 & $(-) 42.240$ & $355.85^{\mathrm{b}}$ & 600 & $(-) 40.692$ \\
\hline THAIMINE (mg) & $1.23^{\mathrm{a}}$ & 1.7 & $(-) 27.765$ & $1.39 \mathrm{~b}$ & 1.4 & $(-) 0.714$ \\
\hline RIBOFLAVIN (mg) & $0.57^{\mathrm{a}}$ & 2.1 & $(-) 72.857$ & $0.74 \mathrm{~b}$ & 1.7 & $(-) 56.629$ \\
\hline NIACIN (mg) & 17.54 & 21 & $(-) 16.453$ & 18.41 & 16 & $(+) 15.086$ \\
\hline VITAMIN C (mg) & $44.55^{\mathrm{a}}$ & 40 & $(+) 11.383$ & $53.71^{\mathrm{b}}$ & 40 & $(+) 34.267$ \\
\hline
\end{tabular}

Different super scripts $\left(\mathrm{a}^{\mathrm{o}} \mathrm{b}\right)$ used for the mean values in male than their respective female groups are statistically significant at $\mathrm{p}<0.05$ level.

Minerals: The consumption of Iron and Calcium has been considered in this study. The intake of these minerals has been found to be in deficit among the agricultural laborers. The Calcium intake is deficit by $42.17 \%$ and $42.27 \%$ in case of male and female agricultural laborers respectively. Likewise, the iron intake is deficit by $36.57 \%$ and $49.68 \%$ in case of male and female agricultural laborers respectively. This is because of fewer intakes of iron rich food, faulty cooking process and faulty selection of vegetables. Some of respondents grow calcium and iron rich vegetables but they do not consume it, rather they sell it in the local market for money.

Vitamin A: The consumption of Vitamin A was $346.5 \mu \mathrm{g}$ and $355.85 \mu \mathrm{g}$ by male and female agricultural laborers respectively. This is $42.24 \%$ and $40.69 \%$ deficit. This may be due to ignorance and less nutritional knowledge.

Thiamine: It is an important B-group vitamin. It is required for the proper utilization of carbohydrates in the body and for full utilization of sugars and starches for meeting the energy needs. The consumption of thiamine is $1.23 \mathrm{mg}$ and $1.39 \mathrm{mg}$ by male and female agricultural laborer which is $27.76 \%$ and $0.714 \%$ deficit from the RDA standard respectively. Compared to other nutrients the deficit intake of thiamine is negligible.

Riboflavin: It is essential for several oxidation processes inside the cell and is concerned with energy and protein metabolism. Daily intake of Riboflavin is $0.57 \mathrm{gm}$ and 0.74 gm by male and female agricultural laborer respectively, which is $72.85 \%$ and $56.62 \%$ deficit from the RDA. This may be due to the lesser consumption of food as compared to recommended quantity. Milk, milk products, eggs, liver are good sources of riboflavin, while wheat, millets and pulses are fair sources. It is recorded earlier that the intake of above items is less which is the main cause of deficit of riboflavin.

Niacin: It is a vitamin intimately connected with several metabolic reactions. Hence its necessity is also related to energy requirement. The Table -2 implies that the average intake of Niacin was $17.54 \mathrm{gm}$ and $18.41 \mathrm{gm}$ respectively which is $16.45 \%$ deficit in case of male agricultural laborer but $15.08 \%$ excess in case of female agricultural laborer. The variation may be due to those whole cereals, pulses are good sources of niacin which were consumed more by women group than male agricultural laborer. The finding of niacin intake by female agricultural laborer of this study lend support to the findings of Bellurkar (2015) ${ }^{22}$ who says that the niacin intake of the respondents was quite normal by female agricultural laborer.
Vitamin C: It is an essential nutrient for human body as it lacks the capacity for synthesis as in case of other animal species. The average intake of Vitamin C is $44.55 \mathrm{mg}$ and $53.71 \mathrm{mg}$ by male and female agricultural laborer which is $11.383 \%$ and $34.26 \%$ excess than recommended amount. This excess intake may be as they take more citrus fruits like lemon and tomatoes, green chilies etc.

A therapy is curing of a disease or alleviating pain or injury by a single or combination of medicines ${ }^{23-25}$. Many a time, diet is used for the treatment of disease(s) ${ }^{24}$. For example, in case of wound healing, supportive diets, especially animal proteins are recommended in many clinical cases other than externally used antibiotics 24-28. Such food substances, different from pharmaceuticals, are more often called as "having medicinal properties,". They are used for therapeutic purposes, can have important role on physiology and even longevity of human 27, 29-32. When the former are purified from animal or plant, they are usually called as biopharmaceuticals 33. More particularly, the term "nutraceuticals" is used when food or products derived from food are used as supplements for therapeutic purposes 3, 3435 . Vitamins, minerals, high-density fatty acids, and herbal products are a few examples 26, 34-35. And, proper nutraceutical intake has lot of importance in every individual including farmers. So, the parameters studied in this work are extremely important for devising a proper plan in daily dietary managements in ALs of Sambalpur 36-38. Methods for investigating both environmental and nutritional impact on food availability and uptake must be carried out $39-40$.

Recommendations: In view of the above results and the foregoing discussion the following steps are suggested which may improve the nutritional status of the agricultural laborer.

- The intake of all food groups except cereals should be increased so that the nutritional value of the food they consume also increases.

- Some locally available fresh fruits like papaya, mango, guava, etc., iron-rich vegetables and some raw vegetables should be included in the diet in order to enrich the quality of foods

- Proper method of cooking is to be followed to retain the nutritive value of the foods. The common practices such as washing of vegetables after cutting, cutting vegetables in small size, draining of excess water after boiling should be avoided. 
- To enhance the quality of the diet, it is essential to include whole cereals and pulses etc. in the menu.

- Germination and fermentation enhance the nutritive value of foods without any additional cost. Thus, sprouted grains and legumes should be included in the meal, which should be eaten raw. Fermented mixture of rice and legumes should be tried.

- Steps should be taken to educate the agricultural laborer on fundamentals of nutrition and role of good nutrition in improving the work efficiency. Nutritional education should focus on selection of low-cost nutritious food. Investigation on low cost alternate food stuffs may also be carried out.

\section{CONCLUSION:}

In the present investigation, it was noticed that the daily food and nutrient intake was below the RDA norms. The nutrient intake of agricultural laborer in this study in Sambalpur area was found below the recommended value for energy, protein, fat, iron, calcium, and vitamin A. The result collaborates the findings of Achinihu et al. ${ }^{41}$ who noticed in their study that the respondents were taking lesser nutrients. Many nutrients were found to be deficit as the respondents take fewer amounts of food items. Therefore, a proper management of nutraceuticals in the studied population is recommended.

\section{ACKNOWLEDGEMENTS}

Scheme number No. ECR/2016/001984 by SERB and 1188/ST, Bhubaneswar, dated 01.03.17, ST-(Bio)-02/2017 and DST, Odisha to BRP are acknowledged.

\section{REFERENCES}

1. USNLM, 2019. Joint Collection Development Policy: Human Nutrition and Food. 2014. US National Library of Medicine, National Institutes of Health. 14 October 2014. Retrieved 13 December 2014.

2. Whitney E, Rolfes, SR. 2013. Understanding Nutrition (13 ed.). Wadsworth, Cengage Learning. pp. 667, 670. ISBN 978-1-13358752-1.

3. Paital B. 2018. Nutraceutical values of fish demand their ecological genetic studies: a short review. The Journal of Basic and Applied Zoology 79: 16. doi.org/10.1186/s41936-0180030-x

4. Food and Agricultural Organization of the United Nations; 2017. FAO, IFAD, UNICEF, WFP and WHO, The State of Food Security and Nutrition in the World. Available

from: http://www.fao.org/3/a-I7695e.pdf. Accessed on September 10, 2018

5. IFPRI. 2017. The Global Hunger Index 2017: the inequalities of hunger. International Food Policy Research Institute. Washington D.C.

6. National Nutrition and Monitoring Bureau (NNMB) Technical report No, 22.available from : http://www.nnmbindia.org/NNMB\%20MND\%20REPORT\%20 2004-web.pdf. Retrieved on 28.8.19

7. Kumar A. 2001. Census as Social Document 127, New Delhi: Anmol Publications, 2002

8. Nampoothiry M.M. 2001. Agriculture Statistics at a Glance 54, New Delhi: Arihant Offset

9. Research Foundation Science and Technology, Impact of WTO on Women in Agriculture 3, New Delhi: National Commission for Women, 2005.

10. Padhi K. 2007. Agricultural Labour in India - A Close Look. Orissa Review (2007), pp 24-27).

11. HPS. 2019. Hirakud Power System. Odisha Hydro Power Corporation. Archived from the original on 13 September 2010. Retrieved 22 August 2019.

12. HAD. 2019. Hirakud Dam Archived 2 November 2008 at the Way back Machine, Retrieved 22 August 2019.
13. RH. 2019. Report on Hirakud. The Indian Express. 2 March 1953. p. 3. Retrieved 22 August 2019.

14. MRA. 2019. Mahanadi River. Archived from the original on 24 November 2006. Retrieved 22 August 2019.

15. Hirakud Power System. 2019. Odisha Hydro Power Corporation. Archived from the original on 13 September 2010. Retrieved 22 August 2019.

16. Hirakud Dam Archived 2 November 2008 at the Wayback Machine, Retrieved 22 August 2019.

17. Report on Hirakud. The Indian Express. 2 March 1953. p. 3. Retrieved 22 August 2019.

18. Mahanadi River. Archived from the original on 24 November 2006. Retrieved 22 August 2019.

19. Govt. of Odisha. 2019. Farmers of Odisha. 2014. https://farmer.gov.in/imagedefault/handbooks/BooKLet/ODIS HA/20151127132510_Agriculture\%20Statistics_2013-14.pdf Retrieved on 28 August 2019.

20. Gopalan C, Sastri RBV, Balsubramanian SC. 2004. Nutritive Value of Indian Foods. Revised and updated by Narasinga, B. S., Deosthale, Y. G. and Pant, K.C. National Institute of Nutrition, Indian Council of Medical Research, Hyderabad, India.

21. Indian Council of Medical Research 2010. Recommended Dietary Intakes for Indians. , New Delhi: ICMR.

22. Bellurkar CM. 2015. Daily Food Intake and Nutrient Intake by the Farm Women. International Journal of Scientific and Research Publication, 11(3): 570-574

23. Hati AK, Paital B, Naik KN, Mishra AK, Chainy GBN, Nanda LK. 2012. Constitutional, organopathic and combined homeopathic treatment of benign prostatic hypertrophy: A clinical trial. Homeopathy, 101, 217-223. doi.org/10.1016/j.homp.2012.08.005

24. Paital B. 2017. Redox regulation in animals to slow down ageing. Journal of Bioresearch Communications, 1(1), 1-2.

25. Sahoo AR, Paital B, Taneja D, Hati AK. 2017. Knowledge, attitude and practice of Anganwadi workers on homoeopathic formulations. Indo American Journal of Pharmaceutical Research, 7(10), 574-581

26. Shankar U, Hati AK, Prusrty U, Prusty U, Panda U, Paital B. 2019. Importance of Diet/Nutrition and Regimen in Homoeopathic Treatment. Journal of Drug Delivery and Therapeutics, 9(3), 575-583. doi.org/10.22270/jddt.v9i3.2801

27. Radinnurafiqah M, Paital B, Kumar S, Abubaker S, Tripathy S. 2016. $\mathrm{AgNO}_{3}$ dependant modulation of glucose mediated respiration kinetics in Escherichia coli at different $\mathrm{pH}$ and temperature. Journal of Molecular Recognition, 29(11), 544554. doi.org/10.1002/jmr.2554.

28. Paital B. 2014. Modulation of redox regulatory molecules and electron transport chain activity in muscle of air breathing fish Heteropneustes fossilis under air exposure stress. Journal of Comparative Physiology. B 184, 65-76. doi.org/10.1007/s00360-013-0778-8

29. Mahawar MM, Jaroli DP. 2008. Traditional zootherapeutic studies in India: A review. Journal of Ethnobiology and Ethnomedicine. 4, 17

30. Paital B, Jahan T, Priyadarshini S, Mohanty A. 2017. Antioxidants and ageing. Open Journal of Environmental Biology, 2(1), 021022.

31. Paital B, Hati AK, Nayak C, Mishra AK, Nanda LK. 2017. Combined effects of constitutional and organopathic homeopathic medicines for better improvement of benign prostatic hyperplasia cases. International Journal of Clinical \& Medical Images, 4(7), 1-2. doi.org/10.4172/23760249.1000574.

32. Paital B, Panda SK, Hati AK, Mohanty B, Mohapatra MK, Kanungo S, Chainy GBN. 2016. Longevity of animals under reactive oxygen species stress and disease susceptibility due to global warming. World Journal of Biological Chemistry. 7(1), 110-127. doi.org/10.4331/wjbc.v7.i1.110.

33. Pedrono F, Martin B, Leduc C, Le-Lan J, Saiag B, Legrand P, et al. 2004. Natural alkyl glycerols restrain growth and metastasis of grafted tumors in mice. Nutrition and Cancer, 48(1), 64-69.

34. Subudhi U, Das K, Paital B, Bhanja S, Chainy GBN. 2008. Alleviation of enhanced oxidative stress and oxygen consumption of L-thyroxin induced hyperthyroid rat liver mitochondria by vitamin E and curcumin. Chemico- Biological Interactions, 173, 105-114. doi.org/10.1016/j.cbi.2008.02.005.

35. Subudhi U, Das K, Paital B, Bhanja S, Chainy GBN. 2009. Supplementation of curcumin and vitamin E enhances oxidative 
stress, but restores hepatic histoarchitecture in hypothyroid rats. Life Sciences, 84, 372- 379 . doi.org/10.1016/j.lfs.2008.12.024.

36. Joint Collection Development Policy: Human Nutrition and Food. 2014. US National Library of Medicine, National Institutes of Health. 14 October 2014. Retrieved 13 December 2014.

37. Camus MF, Piper MD, Reuter M. 2019. Sex-specific transcriptomic responses to changes in

the nutritional environment. Elife. 8. pii: e47262. doi: 10.7554/eLife.47262.

38. Gonmei Z, Toteja GS. 2018. Micronutrient status of Indian population. Indian J Med Res. 2018 Nov; 148(5): 511-521. doi: 10.4103/ijmr.IJMR_1768_18
39. Paital B, Chainy GBN. 2013. Modulation of expression of SOD isoenzymes in mud crab (Scylla serrata): effects of inhibitors, salinity and season. Journal of enzyme inhibition and medicinal chemistry. 28 (1), 195-204

40. Paital B. 2014. A modified fluorimetric method for determination of hydrogen peroxide using homovanillic acid oxidation principle. BioMed research international. 2014, 1-11. doi.org/10.1155/2014/342958

41. Achinihu GA, Mbah CA, Obi-Anyanwu JN. 2016. Nutritional Assessment of Rural Farmers in IMO State , Nigeria ,Implication for Health and Well Being , International Journal of Advanced Academic Research, 2(4):7-18 